\title{
MODELE MYŚLENIA TEOLOGICZNEGO
}

\section{MODELS OF THEOLOGICAL THINKING}

The article attempts to present the advantages of using models in theology in the context of contemporary methodological challenges. The use of renewed hermeneutics can help to reorganize theological thinking to avoid both treating the content of faith in a matter-of-fact manner and reducing it to personal experience. At the same time, fruits of this thinking can be presented in the form of theological models that are simplified representations of a more complex structure. They must not be overly reductive but as holistic, multifaceted, dynamic, and practical as possible. One of the important proposals is the nuptial model developed by Cardinal Angelo Scola. Using this model seems to be inspiring when applied to support, among other things, the correct understanding of sacramentology.

Key words: the nuptial mystery, theological model, hermeneutics, Angelo Scola.

\section{Wstęp}

Wśród najważniejszych współczesnych zagadnień, związanych z pytaniem o metodę teologiczną nie da się pominąć zagadnienia formułowania efektów myślenia teologicznego. Propozycją, która zyskuje na popularności i z wielu względów wydaje się warta rozważania jest posługiwanie się w teologii modelami. Wychodząc od podstawowej definicji modelu, zostaną sformułowane podstawowe zalety posługiwania się nimi w teologii dogmatycznej. Zalety te 
będą związane z jednej strony z uznaniem teologii za dziedzinę wiedzy, która pod pewnymi względami dzieli losy innych dyscyplin naukowych. Z drugiej strony, zalety posługiwania się modelami w teologii dogmatycznej będą związane ze szczególną adekwatnością takiego przedstawiania owoców myślenia właśnie w obszarze Objawienia. Te bardziej teoretyczne założenia zostaną ukazane na konkretnym przykładzie modelu oblubieńczego, przede wszystkim w jego interpretacji zaproponowanej przez kard. Angela Scolę, emerytowanego arcybiskupa Mediolanu ${ }^{1}$.

\section{Zanim powstanie model - kilka współczesnych wyzwań metodologicznych}

Ian G. Barbour, amerykański naukowiec zajmujący się badaniem związkow nauki i religii proponuje podstawową definicję modelu, według której jest on „symbolicznym przedstawieniem, w określonym celu, wybranych aspektów zachowania jakiegoś złożonego systemu" ${ }^{\prime 2}$. W teologii dogmatycznej do tych „wybranych aspektów”, posługując się pewnym uproszczeniem, możemy zaliczyć prawdy wiary, językowy sposób ich wyrażenia oraz powiązanie tych prawd ze sobą. Świadomi rozwoju myślenia teologicznego związanego z niewyczerpanym zasobem treści Objawienia możemy dość szybko zauważyć, że uwzględnienie wymienionych elementów prowadzi raczej do fragmentarycznego opisu struktury niż do stworzenia systemu: jednoznacznego i zamkniętego. Wstępnie więc, posługiwanie się modelami w teologii można uznać za postulat badawczy, oparty na przekonaniu, że wyodrębnienie wszystkich elementów przynależących do systemu bywa w praktyce niekiedy bardzo trudne, bądź wręcz niemożliwe. Aby to zadanie ułatwić, do badania systemów wykorzystuje się ich uproszczone modele.

Taki postulat może wynikać zarówno z przedmiotu teologii, jaki i pewnej ogólnej tendencji we współczesnej nauce. Po oświeceniowym zachwycie wiary w moc nauki wracamy bowiem do bardziej pokornego myślenia o naszych zdolnościach do badania rzeczywistości. Nie tylko w naukach społecznych, ale także w naukach ścisłych możemy dostrzec powolną tendencję do pogodzenia się z tym, że nasza zdolność do opisywania rzeczywistości jest jednak

$\overline{1}$ Znacznie obszerniejsze opracowanie w tym względzie myśli tego autora można znaleźć w: A. Krupka, Tajemnica zaślubin jako model uprawiania teologii w ujęciu Angela Scoli, Kraków 2020. W niniejszym opracowaniu skupimy się na teoretycznych rozważaniach dotyczących używania modeli w teologii, a także wykazania, w jaki sposób narzędzie metodologiczne opracowane w powyższej publikacji ma swoje konkretne zastosowanie, zwłaszcza w sakramentologii.

2 I. G. Barbour, Mity, modele, paradygmaty. Studium porównawcze nauk przyrodniczych i religii, Kraków 1984, s. 10-11. 
fragmentaryczna. Wiemy dużo, mamy coraz lepsze narzędzia do opisywania rzeczywistości. Ale wątpliwe jest, czy kiedyś dojdziemy do etapu, w którym rzeczywiście przy pomocy szkiełka i oka będziemy w stanie w sposób wyczerpujący i całkowicie spójny opisać świat, nawet tylko ten fizyczny.

Co więcej, po zachwycie, ale też metodologicznej konieczności podziału wiedzy na bardzo szczegółowe dziedziny widzimy coraz większą potrzebę syntezy. Dostrzegamy niebezpieczeństwo utraty perspektywy całości, co w teologii będzie także oznaczało trudność z aplikacją twierdzeń do życia wiary. W codziennym życiu możemy tego doświadczyć choćby w czasie wizyty u lekarza, w trakcie której niejednokrotnie jesteśmy redukowani do organu sprawiającego kłopot. Ale im poważniejsza jest choroba, tym większy opór, aby zniknął ten zwykły ludzki element: pacjent, czyli człowiek. Nie mówiąc o zaletach holistycznego rozumienia leczenia w postaci uwzględnienia np. dostosowania diety czy troski o stan psychiczny. Życzylibyśmy sobie, aby synteza nie była abstrakcyjna, ale właśnie podmiotowa, a więc uwzględniająca element subiektywny.

Inaczej, czego przykładem w historii myślenia może być strukturalizm, możemy dojść do etapu, w którym zbudowany system będzie tak wysoce teoretyczny, że w ogóle nie będzie dotykał życia, na co jak wiemy, w teologii w żadnym przypadku nie możemy sobie pozwolić ${ }^{3}$. Co nie oznacza, że sam etap badania językowych systemów czy porównywania dyskursów, do czego zachęca nas poststrukturalizm należy uznać za zbędne ${ }^{4}$. Należy raczej przyznać, że są to tylko narzędzia i jako takie, same w sobie są niewystarczające. Prostym przykładem z samego centrum teologii jest obserwacja, że nie wystarczy porównać ze sobą sposób używania pojęcia Trójcy w tekstach liturgicznych, aby mieć pełny obraz treści tej prawdy wiary. Podobnie, nie wystarczy językowa analiza tekstu biblijnego (czy tekstów Magisterium Kościoła), aby w pełni zrozumieć zarówno jego twórcę, jak i adresata.

Pojawia się pytanie, jak więc tworzyć taką teologię, która byłaby bardziej adekwatna, czyli zawierająca w sobie także praktyczną aplikację? Zanim przedstawimy możliwość adekwatnej teologii trzeba jeszcze chwilę zatrzymać się na tym, co jest jej warunkiem: na adekwatności samego myślenia teologicznego. Za przywołanym już I. G. Barbourem można przypomnieć, że wszystkie modele $\mathrm{w}$ teologii, tak jak modele w naukach przyrodniczych, są oparte na zasadzie

3 Po podstawowe informacje na temat strukturalizmu (zwłaszcza jego historycznych początków) można sięgnąć do: B. Szymańska, Co to jest strukturalizm?, Kraków 1980, s. 6-18.

4 Por. P. Dybel, Oblicza hermeneutyki, Kraków 2012. W publikacji warto zwrócić uwagę przede wszystkim na określenie linii rozwojowej: strukturalizm - hermeneutyka - poststrukturalizm. Zob. s. 37-86. 
analogii ${ }^{5}$. Nie wchodząc szczególowo w rozważania o różnicy pomiędzy teologią a innymi naukami możemy jednak podkreślić szczególne rozumienie i wyjątkowe podstawy analogii w teologii. Po pierwsze, to rozumienie analogii wynika z przekonania o jedności rzeczywistości duchowej i materialnej. Wraz z tajemnicą Wcielenia objawiła się w radykalny sposób prawda, że nie ma nieciągłości pomiędzy tym, co Boskie a tym, co ludzkie. W formie postulatu metafizycznego (i konsekwentnie metodologicznego) zostało to sformułowane przez bardzo wczesne interpretacje treści wyrażonej w formie dogmatu chalcedońskiego i jest obecne także we współczesnej teologii ${ }^{6}$. Przypominając sobie sobór i sposób jego recepcji treści możemy zauważyć, że nie można treści tego dogmatu ograniczać do zrozumienia samej tajemnicy zjednoczenia natur w jednej osobie przedwiecznego Słowa. Należy go traktować raczej jako uniwersalny, metafizyczny postulat opisywania relacji między tym, co Boskie a tym, co ludzkie.

\section{Hermeneutyka jako (częściowa) odpowiedź na współczesne wyzwania metodologiczne}

Wiedząc, że chcemy uniknąć zarówno rzeczowej abstrakcji treści wiary, jak i ograniczenia jej do subiektywnego doświadczenia religijnego, można spróbować poszukać trzeciej drogi między dwoma skrajnościami. Metodą, z której warto zaczerpnąć (nie tylko w teologii) jest hermeneutyka? ${ }^{7}$. Jej historię i teologiczne znaczenie można $\mathrm{w}$ dużym uproszczeniu streścić, mówiąc o niej: znana starożytnym, zakwestionowana przez Marcina Lutra i powracająca we współczesności w odnowionym wydaniu. Aby wyjaśnić teologiczną użyteczność hermeneutyki, możemy rozpocząć od zastrzeżenia, że hermeneutyka, jako teoria interpretacji oznacza coś szerszego niż samo pojęcie „zrozumienia”. Gadamer streszcza to w tytule swojej najważniejszej publikacji, pisząc, że interesuje nas zarówno prawda, jak i metoda (w ich nierozerwalnym związku). Trzeba jednak zastrzec, że samo słowo „metoda” nie jest najwłaściwsze dla hermeneutyki. Jej zadaniem bowiem jest nie tyle rozwijanie samej procedury rozumienia, co raczej wyjaśnienie warunków rozumienia ${ }^{9}$. W takim sensie, jest ona bardziej

$5 \quad$ O analogiczności modeli teologicznych: S. Kołata, Komplementarność modeli w teologii trynitarnej, Kraków 2017, s. 35-38.

6 Por. R. J. Woźniak, Wcielenie Boga i historia cztowieka, „Znak” 647 (2009), s. 81-91.

7 Oznaczeniu dynamiki między (post) strukturalizmem a hermeneutyką dla teologii można przeczytać więcej w: A. Krupka, Tajemnica zaślubin..., s. 50-67.

8 Por. W. G. Jeanrond, Hermeneutyka teologiczna. Rozwój i znaczenie, Kraków 1999, s. 13-14.

9 Por. H.-G. Gadamer, Prawda i metoda. Zarys hermeneutyki filozoficznej, Warszawa 2004, s. 406 . 
sztuką rozumienia niż zbiorem procedur, znanym z nauk przyrodniczych. Temu podejściu właściwe jest także przekonanie o jedności rzeczywistości, jednak z koniecznym dopowiedzeniem, że rzeczywistość jest różnie dana człowiekowi w jego doświadczeniu. Relacje w świecie duchowym są inne niż przyczynowe relacje świata przyrodniczego. Konsekwentnie oznacza to, że przyczyna jest obecna w skutku inaczej niż słowo w swoim wyrazie ${ }^{10}$.

Co ważne z punktu widzenia użyteczności hermeneutyki dla teologii, ta odmienność nie oznacza braku zewnętrzności oraz skupienia się jedynie na subiektywności i zmienności. Rozważania o rzeczywistości przekonują, że także życie duchowe ma swoją określoną strukturę, która jest czymś danym (w teologii warto od razu dodać postulat praktyczny: ta struktura życia duchowego jest także czymś zadanym). Świadomość zaś jest procesem, w którym kształtuje się indywidualność jako dynamika pomiędzy wolnością a doświadczeniem ograniczenia przez warunki. Tak pojmowaną strukturę można zrozumieć wyłącznie $z$ jej własnego centrum ${ }^{11}$.

Upraszczając można powiedzieć, że hermeneutyka będzie szczególnie pomocna w równoległym widzeniu elementu subiektywnego i obiektywnego w jednej rzeczywistości wiary. Jej niewątpliwą zaletą jest także dynamizm i ciągłość procesu rozumienia, zarówno w sensie kwestionowania jego wyników, jak może przede wszystkim weryfikowania i uzupełniania tworzonego obrazu, czy mówiąc wybranym tu językiem - modelu. Jednocześnie, hermeneutyka w kontrze do oświeceniowych metod badawczych, nie odrzuca roli autorytetu, uznając, że nie tylko rozum, ale także np. tradycja ma swoje podmiotowe znaczenie ${ }^{12}$. Tak jakby tradycja nie polegała na odczytywaniu historycznie skończonych tekstów, ale sama była rozmówczynią w procesie odczytywania depozytu wiary; rozmówczynią, z którą ciągle można wejść w twórczy dialog. Celem zaś tego dialogu jest pogłębianie zrozumienia codziennego doświadczenia oraz wypracowywanie konkretnych rozwiązań praktycznych (np. etycznych).

Co więcej, hermeneutyka podkreśla, że pewnego rodzaju „uprzedzenia”, czyli przedzałożenia stanowią w ogóle warunek rozumienia. Ich istnienie jest także potwierdzeniem tego, że rozumienie nie jest działaniem ograniczonym do subiektywności ${ }^{13}$. Jest to raczej „wejście w proces przekazu tradycji, w której przeszłość i teraźniejszość są stale zapośredniczone”14. W taki sposób umacnia się też przekonanie, że dialektyka procesu rozumienia nie oznacza opozycyjności

\footnotetext{
$10 \quad$ Por. tamże, s. 314-315.

11 Por. tamże, s. 325-323.

12 Por. tamże s. 501-505.

13 Por. tamże, s. 400.

14 Tamże.
} 
normatywności i historyczności. Prawo i dogmaty byłyby przecież pozbawione istotnych wymiarów swojego sensu bez odkrycia historyczności ich poznania oraz procesu rekonstrukcji ich oddziaływania (czyli np. bez uwzględnienia recepcji nauczania Kościoła). Przykład tego dobrze widać w znanym napięciu pomiędzy Jezusem historii a Chrystusem wiary.

Ten proces docierania do głębszego rozumienia rzeczywistości właściwie nie ma kresu. W tym sensie, wydaje się to odpowiadać tak przedmiotowi teologii, jak i kościelnemu przekonaniu, że objawiający się Bóg jest zawsze większy od sposobu, w jaki się objawia i od form, w których to Objawienie można zapisać. Sam Gadamer stwierdza, że Zły to „hermeneuta, który sobie wyobraża, że może lub że musi mieć ostatnie słowo" ${ }^{15}$. Jest to słuszne także w perspektywie doczesnej, jak i wiecznej, w której stworzenie nadal pozostanie tylko stworzeniem, a proces odkrywania tajemnicy Boga nigdy się nie skończy.

Rozważania o rozumieniu trzeba także uzupełnić uwagą o jego strukturze. $\mathrm{Z}$ metodami hermeneutycznymi nieodłącznie jest związane pojęcie koła hermeneutycznego. Za Jeanrondem możemy przypomnieć jego dwa podstawowe znaczenia ${ }^{16}$. Po pierwsze, oznacza ono, że sam proces rozumienia ma taką właśnie strukturę: kolistą lub spiralną. Jako taki, jest dynamiką pomiędzy pytaniami i odpowiedziami. Czytelnik nie czyta tekstu bez podstawowego pytania o jego rozumienie. W miarę jednak jak zagłębia się w tekst, pojawiają się nowe pytania, a stare są korygowane przez rosnące rozumienie tekstu. Po drugie, kolista struktura rozumienia oznacza, że nie jest możliwe zrozumienie części tekstu bez odniesienia do całości. Analogicznie jednak: nie jest także możliwe zrozumienie całości bez wyjaśnienia poszczególnych części teksu. Kiedy pomyślimy o „czytelniku świata stworzonego przez Boga”, czyli żyjącym i myślącym człowieku, to wiemy, że postępując na drodze wiary weryfikuje on swoje bardziej pierwotne przekonania i postawy. Trwa jego chrześcijańska tożsamość, ale zmienia się ona wraz z jego rozwojem duchowym (którego częścią jest także rozwój wiedzy). Zarówno wzrost dojrzałości, jaki i przedefiniowanie postaw nie muszą być rozumiane jako negacja tego, co wcześniejsze. Jeśli za podstawową cechę życia chrześcijańskiego uznamy dyspozycję do ciągłego nawracania, to właśnie pokusa stabilności i odnalezienia zamkniętych odpowiedzi wydaje się być jednym z większych zagrożeń. Co więcej, spotkanie z Ewangelią zawsze na pewnym etapie jest związane $z$ utratą oczywistości; jest szokujące i prowadzi do dekonstrukcji starych, utartych schematów ${ }^{17}$.

15 H.-G. Gadamer, Prawda i metoda..., s. 757.

16 Por. W. G. Jeanrond, Hermeneutyka teologiczna..., s. 17-18.

17 Por. J. Werbick, Wprowadzenie do epistemologii teologicznej, Kraków 2014, s. 189-192. 
Pokrótce, właśnie w taki sposób hermeneutyka może redefiniować rozumienie wiary, natomiast w samej teologii pewnego rodzaju „rozliczenie się” $z$ metodami hermeneutycznymi możemy znaleźć w dokumencie Międzynarodowej Komisji Teologicznej Interpretacja dogmatów, opublikowanym w 1988 $\mathrm{roku}^{18}$. Z wielu cennych myśli tego dokumentu warto podkreślić konieczność myślenia metafizycznego. Hermeneutyka bez metafizyki (przekonania o spójnej prawdzie rzeczywistości) istotnie staje się tylko opisem zmienności rozumienia.

\section{Struktura myślenia teologicznego}

Jeśli do pewnego stopnia udało się wykazać znaczenie dla teologii przeciwstawienia (post)strukturalizmu i hermeneutyki jako metod badawczych, to kontynuację tych rozważań powinna stanowić refleksja nas sposobami systematyzacji wiedzy teologicznej. Można więc na początek postawić tezę, że skoro przedmiot teologii jest nieograniczony, to także sposób wyrazu teologicznych prawd nie może zmierzać w kierunku przedstawienia ich w formie całościowego systemu. Tego rodzaju antysystemowości, która wydaje się być konieczną cechą teologii, nie należy jednak uznawać za pochwałę negatywności, a raczej zachętę do krytycznego weryfikowania sposobów wyrażania myślenia teologicznego ${ }^{19}$. Dlatego też, szczególnie dla teologii dogmatycznej, istotne wydaje się być pokazanie niezbywalnego związku pomiędzy prawdą, sposobem jej poznania i możliwościami wyrażania.

Mówiliśmy już o metafizycznej podstawie dogmatu chalcedońskiego. Warto jeszcze przypomnieć kilka myśli wynikających z centralności Jezusa Chrystusa, aby przejść do próby ukazania powyższych postulatów w sposób bardziej praktyczny i dynamiczny. Hermeneutyczną nowością, właściwą pierwszym chrześcijańskim wspólnotom jest chrystologicznie skoncentrowany sposób lektury tekstu biblijnego. To wczesne podejścia do interpretacji tekstów biblijnych kształtuje znane napięcie pomiędzy szkołą antiocheńską i aleksandryjską. Te dwa odmienne podejścia dotyczyły nie tylko czytania Pisma Świętego, ale konsekwentnie prowadziły do odmiennego sposobu opisania tajemnicy Chrystusa. Warto więc - pamiętając o tym etapie rozwoju teologii - mieć na uwadze, że przyjęta metoda teologiczna prowadzi nie tylko do określonego sposobu czytania tekstów religijnych, ale także wyznacza modus postrzegania i opisywania całej rzeczywistości.

Dzięki temu, że interpretowalność może być uznana za funkcję tradycji, to właśnie współczesne połączenie metod historyczno-krytycznych oraz

$18 \quad$ Wydanie polskie w: Od wiary do teologii. Dokumenty Międzynarodowej Komisji Teologicznej 1969-1996, (red.) J. Królikowski, Kraków 2000, s. 273-302.

19 Więcej także w: A. Krupka, Tajemnica zaślubin..., s. 63-76. 
hermeneutyki przyniosło teologii i Kościołowi pewne ożywienie. Hermeneutyka teologiczna jako ciągła interpretacja tekstów religijnych ma przynajmniej dwie ważne cechy, które wydają się odpowiadać posoborowemu rozumieniu rzeczywistości Kościoła. Z jednej więc strony, prowadzi do wzrostu samoświadomości. Uzupełnianie narzędzi badawczych i aparatu krytycznego pozwala na poszerzenie wiedzy nie tylko o samym procesie powstawania świętych tekstów, ale wpływa także na samorozumienie wspólnoty, dla której są one częścią Tradycji. Z drugiej strony, to pogłębianie samoświadomości pomaga w aktualnym odczytywaniu historycznych tekstów. Jeśli traktujemy źródła wiary nie tylko jako spisany tekst, ale szerzej jako sposób komunikacji, łatwiej jest traktować te religijne teksty jako zasady życia tu i teraz.

Tym, co wymaga dookreślenia, jest to, w jaki sposób taka perspektywa zmienia lekturę nie tylko tekstu biblijnego, ale także odczytywanie formuł dogmatycznych. Szczególowo na kwestię zastosowania metod hermeneutycznych w samej dogmatyce zwraca uwagę m. in. Walter Kasper. Harald Wagner, referując poglądy niemieckiego kardynała, podkreśla, iż odejście od metod spekulatywnych $w$ teologii doprowadziło do zmiany postrzegania samego dogmatu: stał się on pojęciem relacyjnym, będąc efektem uwarunkowanej historycznie odpowiedzi udzielanej przez Kościół, poprzez odniesienie do Pisma i Tradycji. Jak pisze Kasper: „Dogmatyka, uwzględniająca taki właśnie proces powstawania dogmatów, pojmuje siebie jako hermeneutykę [...] Wychodząc od hermeneutycznej koncepcji H. G. Gadamera, pragnie ona zastanawiać się nad historią oddziaływania biblijnych świadectw objawienia i pragnie uczynić je aktualnymi dla współczesności. Tak rozumiana, jest więc procesem przekładu, który przejętą historię stara się przedstawiać jako przyszłą; stosująca metodę hermeneutyczną dogmatyka pragnie przez krytyczną recepcję tradycji dogmatycznej przekazywać ją aktywnie wraz z własną sytuacją. Dogmatyka taka możliwa jest nie jako system zamknięty, lecz jedynie jako historycznie otwarty"20.

Częścią otwartości systemu jest także zwrócenie uwagi przez współczesną hermeneutykę na znaczenie języka, którym odkrywana prawda jest opisywana. Hermeneutyka przekonuje, że teologia powinna rozszerzyć swoje badawcze zainteresowanie, tak aby uwzględnić nie tylko prawdę dogmatu, jak i jej językowy sposób wyrażania ${ }^{21}$. Język zawsze ma w sobie zamiar wyrażenia tego, co przekracza konkretny przypadek, który opisuje. Dobrze oddaje to obecność analogii

20 W. Kasper, Dogmatik als Wissenschaft. Versuch einer Neubegründung, ThQ 157 (1977), s. 195-196, cytat za: H. Wagner, Dogmatyka, Kraków 2007, s. 47.

21 Por. A. Perzyński, Metoda teologiczna wedtug Szkoty Mediolańskiej. Studium historyczno-dogmatyczne, Warszawa 2006, s. 218-223. 
w języku, opartej na dynamice pomiędzy tożsamością i różnicą 22 . Analogia jest bowiem usytuowana pomiędzy jednoznacznym a całkiem różnym używaniem tego samego pojęcia do rozmaitych przedmiotów. Każde używanie języka, zwłaszcza języka naukowego, ma w sobie cechy analogiczności. Jednak tak naprawdę dopiero język wiary wyjaśnia pełne i właściwe rozumienie analogii ${ }^{23}$. Analogii, która zawiera w sobie jednocześnie moment przyporządkowania i oddzielenia. Analogii, opartej na ciągłości rzeczywistości, dzięki czemu człowiek może realnie uczestniczyć w tym, o czym mówią prawdy wiary. Analogiczność bowiem dotyczy nie tylko sposobu formułowania prawd wiary, ale także ich przeżywania. W konsekwencji skłania do docenienia narracyjności, uznając, że choć wydarzenie zbawcze jest faktem, to jest zrozumiałe tylko we właściwym kontekście narracyjnym ${ }^{24}$.

Jak jednak pogodzić powyższe uwagi o potrzebie systemowej otwartości $z$ wymogiem porządkowania wiedzy teologicznej? Wydaje się, że jedną z dróg poszukiwania odnowionego sposobu uprawiania teologii (uwzględniającego wcześniejsze uwagi tak o hermeneutyce, jak i analogiczności języka) jest przedstawianie twierdzeń teologicznych właśnie w formie modeli.

Po pierwsze, modelowe myślenie w teologii umożliwia zachowanie także implikacji egzystencjalnych. Chociaż pozwala przedstawić treści wiary w sposób symboliczny, unika jednak perspektywy schematycznej i jednoznacznej. Dlatego też formulując propozycję zastosowania modeli w teologii nie odwolujemy się do tych, które charakteryzują się jednoznacznością i abstrakcyjnością. One służą raczej do przedstawienia wycinka materii teologii, niż do bardziej całościowego ujęcia ${ }^{25}$. Barbour zwraca także uwagę, że modele religijne mają także funkcje pozapoznawcze i bardziej odwołują się do osobistego zaangażowania. Można nawet powiedzieć, że oddziałują mocniej niż doktryna, która jest dla nich podstawowa ${ }^{26}$.

Wobec postulatu doceniania poznającego podmiotu i znaczenia osobistego oddziaływania modelu warto przypomnieć współczesną przestrogę, aby antropologii teologicznej nie zmienić $\mathrm{w}$ antropocentryzm teologiczny ${ }^{27}$. Antropologia

22 Por. W. Kasper, Bóg Jezusa Chrystusa, Wrocław 1996, s. 122-124.

23 Por. W. Stróżewski, Istnienie i sens, Kraków 1994, s. 444-449.

24 Por. tamże, s. 110.

25 Takie proste, ograniczone modele ilustrujące pojedyncze dogmaty są znane przede wszystkim $z$ teologii trynitarnej.

26 Por. I. G. Barbour, Mity, modele, paradygmaty..., s. 90-91.

27 Por. A. Zuberbier, Antropologia a teologia. Aspekt teologiczno-systematyczny, [w:] Teologia a antropologia. Kongres Teologów Polskich 21-23 IX 1971, (red.) M. Jaworski, A. Kubiś, Kraków 1975, s. 97. 
teologiczna, jako teologia człowieka, ma swoje niekwestionowane miejsce we współczesnej teologii, m.in. dlatego, że w żadnym innym miejscu teologii nie ukazuje się tak dobrze błąd separacji porządku natury i nadprzyrodzoności ${ }^{28}$. Antropologia teologiczna może także, pod pewnymi warunkami, pełnić syntezę dla całej dogmatyki ${ }^{29}$. Widać to w tendencji do wykazywania związku wszystkich klasycznych traktatów teologii dogmatycznej z antropologią, prowadzące w teologii do właściwie rozumianego antropocentryzmu, opartego na przekonaniu, że tak Objawienie, jak i Odkupienie są skoncentrowane na człowieku ${ }^{30}$. $\mathrm{Z}$ jednej strony, poprawia się nasze rozumienie Magisterium ponieważ dzieli nas od niego dystans, który pozwala lepiej zrozumieć uwarunkowania tych wypowiedzi. Z drugiej jednak strony, pytania o aktualną interpretację depozytu wiary zakładają zawsze uwikłanie w teraźniejszość. Skoro wpływ kontekstu jest niemożliwy do uniknięcia, trzeba jednak starać się dążyć do większej świadomości jego wpływu ${ }^{31}$. Jak pisze Andrzej Zuberbier „teologia antropocentryczna nie jest, czy raczej nie ma być jakimś systemem teologicznym obok innych. Jest ona bardziej postulatem i regułą hermeneutyczną, którą w badaniach teologicznych należałoby konsekwentnie stosować [...]. Ma odróżniać to, co ludzkie od tego, co Boskie. Z tym oczywiście, że chodzi o świadomość nieuniknionego uwikłania tego, co Boskie w to, co ludzkie, a nie o niewykonalne oddzielenie jednego od drugiego" ${ }^{32}$. Konieczne jest jednak podkreślenie, że mówiąc o antropologii teologicznej mamy zawsze na myśli antropologię chrystologiczną, dla której podstawowe jest przekonanie, iż to nie abstrakcyjna natura ludzka jest miarą i normą człowieczeństwa, ale jest nią Chrystus ${ }^{33}$.

\section{Model oblubieńczy i jego zastosowanie}

Po tych bardziej teoretycznych rozważaniach, przedstawiających pewne założenia ważne dla sensownego tworzenia modeli teologicznych warto na konkretnym przykładzie pokazać efekt takiego myślenia. Tą egzemplifikacją może być model oblubieńczy, biblijny i znany starożytnemu Kościołowi, a współcześnie rozwijany m.in. przez emerytowanego biskupa Mediolanu kard. Angelo

\footnotetext{
28 Por. tamże, s. 97-104.

29 Por. A. Nossol, Teologia na ustugach wiary. Wokót zagadnień odnowionej teologii, Opole 1978, s. 41-49.

30 Por. A. Zuberbier, Antropologia a teologia..., s. 103-104.

31 Por. tamże, s. 107-112.

32 Tamże, s. 108.

33 Por. A. Perzyński, Metoda teologiczna wedlug Szkoly Mediolańskiej..., s. 206-212.
} 
Scolę ${ }^{34}$. Model nupcjalny nie tylko obrazuje treść poszczególnych prawd wiary, ale ma wielką zaletę organizowania ich oraz dostarczania języka, który jest podstawowy i uniwersalny, a jednocześnie bardzo głęboki. Co więcej, model oblubieńczy jest ciekawą drogą do wypracowania specyfiki modeli religijnych wobec modeli z innych nauk. Jest on dość mocno rozbudowany, ma jednak wyraźne centrum i zasady analogii. Jako taki, jest bliższy modelom soteriologicznym, które są skupione na tajemnicy Odkupienia. Jest więc właściwy dla porządku zbawczego, poddany posłuszeństwu wobec logiki Objawienia, chociaż jego podstawą jest niezmiennie Trójjedyny Bóg.

Od Starego Testamentu aż do współczesności można dostrzec tendencję, że to właśnie język oblubieńczy jest tym stanowiącym źródłowy i pierwotny sposób opisania misterium Zbawienia, a w nim także podstawowej struktury antropologicznej, przejawiającej się w doświadczeniu miłości ${ }^{35}$. Model oblubieńczy ma swoje źródło w metaforyce Starego Testamentu. Bóg jest opisywano jako Oblubieniec w relacji do Narodu Wybranego - Oblubienicy (np. Iz 62, 1-5, Ez 16), ale także życie małżeńskie (lub jego brak) np. u proroków jest symbolicznym wyrazem więzi Boga i Izraela (tak jest w przypadku małżeństwa Ozeasza i celibatu Jeremiasza). Dobrze znany chrześcijańskiej duchowości ${ }^{36}$, współcześnie w potocznym sensie jest często redukowany do duchowości żeńskiego życia konsekrowanego. Nie tylko dobrze organizuje rzeczywistość prawd wiary, ale można go pod pewnymi względami uznać za uprzywilejowany: w Starym Testamencie jest jednym z kluczowych sposobów opisywania relacji pomiędzy Bogiem i człowiekiem ${ }^{37}$.

Jest także obecny w Nowym Testamencie, jako misterium Chrystusa i Kościoła (kluczowy jest tutaj tekst z Listu św. Pawła do Efezjan: Ef 5, 21-33). Misterium, a więc tajemnica, dzięki której można lepiej zrozumieć symbolicznie opisywaną rzeczywistość. Jednocześnie ta rzeczywistość nigdy nie będzie

$34 \quad$ On sam nie opracowuje tego modelu w sposób systematyczny, wielokrotnie jednak opisuje go i korzysta $z$ niego w swoich publikacjach. Z bogatego dorobku ponad stu książek warto w nupcjalnym temacie sięgnąć przede wszystkim do: Chi è la Chiesa? Una chiave antropologica e sacramentale per l'ecclesiologia, Brescia 2005, Il mistero nuziale. Una prospettiva di teologia sistematica?, Roma 2003 oraz Il mistero nuziale. Uomo-Donna. Matrimonio-Famiglia ${ }^{3}$, Venezia 2014.

35 Sam Scola jedynie bardzo krótko opracowuje zagadnienie oblubieńczości jako struktury podstawowej w: Il mistero nuziale. Orginarietà e fecondità, „Anthropotes”, XXIII (2/2007), s. $57-70$.

36 Można to zobaczyć już w starożytności, np. u Orygenesa i Grzegorza z Nyssy. Zob. Orygenes, Komentarz do „Pieśni nad pieśniami”, Kraków 1994 oraz Grzegorz z Nyssy, Homilie do „Pieśni nad pieśniami”, Kraków 2007.

37 Zob. M.-F. Lacan, Oblubieniec-oblubienica, [w:] Stownik teologii biblijnej, (red.) X. Leon-Dufour, Poznań 1994, s. 586-588. 
poznana w całej swojej głębi. Od razu więc warto podkreślić dwie granice używania tego modelu. Pierwsza, jest wyznaczona już u św. Pawła przez termin tajemnicy. Nie da się do końca wyczerpać opisu tej oblubieńczej relacji, ani wskazać jej wszystkich konsekwencji. Druga granica używania modelu oblubieńczego jest związana z jego aspektem językowym. Język miłości można uznać za język podstawowego doświadczenia człowieka, jednak w tym obszarze bardzo szybko staje się widoczna trudność i ograniczenie w przekładalności języka ludzkiego na rzeczywistość Boską. Można jednak zaryzykować stwierdzenie, że tą trudność należy uznać za zaletę. Tak łatwo można nadużyć dosłowności języka oblubieńczego, że od razu wyczuwalna staje się analogiczność tego języka, opartego na wyjaśnionej wcześniej analogiczności rzeczywistości Boskiej i ludzkiej.

Możemy także dodać, że tajemnica, o które pisze św. Paweł jest konkretna i dotykalna. W centrum modelu jest bowiem nie tylko Chrystus, sam i samotny, ale także Kościół. Umacniają to te dwie pary określeń, nierozerwalnie związane ze sobą w teologii św. Pawła: Oblubieniec i Oblubienica oraz Głowa i Ciało. Wcielony Logos, który ma Ciało, a którego obecnie widzialnym Ciałem jest Kościól. Jest to tak radykalne, że możemy nawet powiedzieć, że po swoim Wniebowstąpieniu tylko Chrystus-Głowa i Kościół-Ciało stanowią całego Chrystusa $^{38}$. Wzmacnia to nie tylko rangę opisywanego przez nas modelu, ale przypomina także o niezbywalności Kościoła i jego strukturalnie-relacyjnym znaczeniu, którego nie można zredukować do poziomu instytucjonalnego oraz uznać go za coś dowolnego.

Widzimy więc Chrystusa, którego nie można zrozumieć samego w sobie, ale który daje się wyjaśnić i objawia się przez relację do Kościoła. Nie tylko jest to więź niezbywalna i cielesna, ale jest to relacja oblubieńcza: wyłączna, trwała i płodna oraz zrodzona z wolności ${ }^{39}$. Relacyjność Chrystusa jest nie tylko kolejnym dowodem na niezbywalność Kościoła, ale także ciekawym argumentem dla teologii imago Dei. Przyzwyczailiśmy się mówić, że człowiek jest podobny Bogu w swojej wolności i rozumności. Czy nie możemy jednak zaryzykować tezy, że najbardziej naśladuje on Boga właśnie wtedy, kiedy realizuje swoją komunijną strukturę ${ }^{40}$ ? Metafora oblubieńcza przypomina, że moglibyśmy tą

38 Por. Katechizm Kościoła Katolickiego², Poznań 2002, 358.

39 Bardzo szerokim tematem do dodatkowych badań jest wzajemna zależność relacji Chrystusa i Kościoła od rozumienia (sakramentalnego) małżeństwa. Tutaj, ze względu na ramy tekstu, przekładalność tych dwóch rzeczywistości jest stosowana dość swobodnie, zwłaszcza w aspekcie dwukierunkowości oblubieńczych wniosków.

40 Por. F. Kerr widzi przede wszystkim zasługi Jana Pawła II dla komunijnej teologii imago Dei, zob. w: Katoliccy teolodzy XX wieku. Od neoscholastyki do mistyki oblubieńczej, Kraków 2011, s. 224-229. 
tezę uzasadnić nie tylko podstawowym dogmatem trynitarnym, ale także tym modelem soteriologicznym.

Jak każda relacja oblubieńcza także ta nie jest redukowalna do dwóch tworzących ją podmiotów, ale jest otwarta i zdolna do przekraczania siebie. Formą tej płodności są sakramenty. Przez nie każdy człowiek może zostać włączony w tajemnicę oblubieńczej relacji, czyli stać się oblubienicą na podobieństwo pierwszej Oblubienicy - Kościoła. Człowiek więc z jednej strony zostaje włączony w tajemnicę oblubieńczości Chrystusa i Kościoła, a z drugiej, jego relacja do Chrystusa staje się analogiczna do tej, jaką ma Kościół jako całość: wymagająca decyzji woli, wyłączna, trwała i płodna.

Długo można by analizować konsekwencje, jakie ma to dla rozumienia chrześcijańskiej tożsamości: jej radykalności, trwałości i intymności. Jednak za wątek najbardziej podstawowy i najciekawszy należałoby uznać przemyślenie w tym kluczu całej sakramentologii, zwłaszcza w aspekcie rozumienia uczestnictwa człowieka w sakramentach. W modelu oblubieńczym oczywiste jest podkreślenie sprawczości nie tylko Chrystusa (w tajemnicy Wcielenia i Zmartwychwstania), ale także niezbywalności Kościoła. Tym, co ma moc w sakramentach jest nie tyle sam Chrystus, co sposób jego obecności w Kościele. Dopiero ta podstawa otwiera drogę dla indywidualnego rozumienia sakramentów. Chrzest, w którym przymierze ślubne zostaje zawarte, ma konsekwencje dla całego życia człowieka poprzez powstanie więzi oblubieńczej, analogicznej do relacji Chrystusa i Kościoła. I tak, jak ludzka więź małżeńska, także ta domaga się podtrzymywania w codzienności i powinna się rozwijać wraz z tymi, którzy ją tworzą.

To, co wydaje się być szczególnie ważne z punktu widzenia stanu refleksji i dynamiki przygotowywania ludzi do przyjęcia sakramentów, to spostrzeżenie, że model oblubieńczy pozwala rozumieć sakramenty bardziej integralnie i dynamicznie. Poszczególne obrzędy są w nim granicznymi i szczytowymi punktami, w których streszcza się więź obejmująca całe życie człowieka. Sporym wyzwaniem współczesnego przygotowania do sakramentów jest ich punktowe rozumienie, skupiające się na doprowadzeniu jedynie do celebracji. Otwarte pozostaje pytanie, na ile widzimy związek poszczególnych sakramentów ze sobą oraz ich więź z codziennym życiem? Dodatkowo, metafora oblubieńcza pomaga oddać sakramentalną dynamikę, która domaga się uwzględnienia tak procesu przygotowania do sakramentów, jak i określenia warunków pogłębiania łaski po przyjęciu sakramentu. 


\section{Zakończenie}

Powyższe rozważania stanowią jedynie zarys tematu stosowania modeli w teologii i w wielu obszarach są zaproszeniem do dalszych badań. Po pierwsze, pojęcie modelu zostało sformułowane dość ogólnie, w oparciu o podstawowe definicje. Zwrócono tu przede wszystkim uwagę na znaczenie chrześcijańskiego rozumienia analogii, jako ważną, a niekiedy pomijaną zasadę odnoszenia do siebie rzeczywistości Boskiej i ludzkiej. Po drugie, także szerokim studiom można by poddać zastosowanie hermeneutyki w teologii. Tutaj poprzestaliśmy na kilku podstawowych wnioskach, dostrzegając przede wszystkim jej zaletę jednoczesnego uwzględniania tego, co obiektywne i tego, co subiektywne. Aby uzyskać metodologiczną jasność należałoby także wykazać swoistość modeli teologicznych wobec modeli stosowanych w innych naukach. Przyjęliśmy, że ta swoistość będzie wynikała z przedmiotu samej teologii, a także z jej niezbędnego wymiaru praktycznego: oddziaływania na życie wierzących. Wreszcie, szczegółowego opracowania domaga się model oblubieńczy. Dysponujemy wieloma historycznymi odwołaniami do tej metafory, które niewątpliwe potwierdzają jej istotne znaczenie. Warto byłoby pokusić się o przepracowanie w kluczu oblubieńczym choćby sakramentologii. Zasygnalizowaliśmy tutaj przede wszystkim, że model oblubieńczy sprzyjałby bardziej integralnemu i osobistemu przeżywaniu sakramentów, wskazując także na niezbywalność Kościoła.

Słowa kluczowe: tajemnica zaślubin, model teologiczny, hermeneutyka, Angelo Scola.

\section{Bibliografia:}

1. Barbour I. G., Mity, modele, paradygmaty. Studium porównawcze nauk przyrodniczych i religii, Kraków 1984.

2. Dybel P., Oblicza hermeneutyki, Kraków 2012.

3. Gadamer H.-G., Prawda i metoda. Zarys hermeneutyki filozoficznej, Warszawa 2004.

4. Grzegorz z Nyssy, Homilie do „Pieśni nad pieśniami”, Kraków 2007.

5. Jeanrond W. G., Hermeneutyka teologiczna. Rozwój i znaczenie, Kraków 1999.

6. Kasper W., Bóg Jezusa Chrystusa, Wrocław 1996.

7. Katechizm Kościoła Katolickiego, Poznań 2002.

8. Kerr F., Katoliccy teolodzy XX wieku. Od neoscholastyki do mistyki oblubieńczej, Kraków 2011.

9. Kołata S., Komplementarność modeli w teologii trynitarnej, Kraków 2017.

10. Krupka A., Tajemnica zaślubin jako model uprawiania teologii w ujęciu Angela Scoli, Kraków 2020.

11. Lacan M.-F., Oblubieniec-oblubienica, [w:] Stownik teologii biblijnej, (red.) X. Leon-Dufour, Poznań 1994, s. 586-588. 
12. Orygenes, Komentarz do „Pieśni nad pieśniami”, Kraków 1994.

13. Perzyński A., Metoda teologiczna wedtug Szkoty Mediolańskiej. Studium historyczno- dogmatyczne, Warszawa 2006.

14. Scola A., Chi è la Chiesa? Una chiave antropologica e sacramentale per l'ecclesiologia, Brescia 2005.

15. Scola A., Il mistero nuziale. Orginarietà e fecondità, „Anthropotes”, 2 (2007), s. $57-70$.

16. Scola A., Il mistero nuziale. Una prospettiva di teologia sistematica?, Roma 2003.

17. Scola A., Il mistero nuziale. Uomo-Donna. Matrimonio-Famiglia, Venezia 2014.

18. Stróżewski W., Istnienie $i$ sens, Kraków 1994.

19. Szymańska B., Co to jest strukturalizm?, Kraków 1980.

20. Wagner H., Dogmatyka, Kraków 2007.

21. Werbick J., Wprowadzenie do epistemologii teologicznej, Kraków 2014.

22. Woźniak R. J., Wcielenie Boga i historia człowieka, „Znak” 647 (2009).

23. Zuberbier A., Antropologia a teologia. Aspekt teologiczno-systematyczny, [w:] Teologia a antropologia. Kongres Teologów Polskich 21-23 IX 1971, (red.) M. Jaworski, A. Kubiś, Kraków 1975, s. 96-114. 